\title{
PERANCANGAN APLIKASI WEB PENYEWAAN LAPANGAN FUTSAL (STUDI KASUS : SUMBER JAYA FUTSAL TANGERANG)
}

\author{
Ika Yuniva ${ }^{1}$, Andriansah ${ }^{2}$, Yoga Nur lkhsan ${ }^{3}$ \\ Universitas Bina Sarana Informatika \\ ika.iya@bsi.ac.id ${ }^{1}$, andriansah.aiy@bsi.ac.id ${ }^{2}$, yayang_sholeh@yahoo.co.id ${ }^{3}$
}

\begin{abstract}
Abstraksi - Olahraga Futsal telah berkembang dan populer di Indonesia. Sumber Jaya Futsal adalah salah satu penyedia bisnis persewaan lapangan futsal di Tangerang. Sumber Jaya Futsal saat ini tidak memiliki sistem berbasis web, sistem untuk penyewaan lapangan futsal di Sumber Jaya Futsal masih konvensional, di mana pelanggan datang langsung atau dengan menelepon untuk mengetahui jadwal lapangan futsal yang tersedia. Penjadwalan transaksi sewa dan sistem pelaporan masih menggunakan notebook. Berdasarkan masalah tersebut, tujuan dari penelitian ini adalah untuk menghasilkan rancangan web aplikasi untuk sewa lapangan futsal di Sumber Jaya Futsal Tangerang. Dalam penelitian ini untuk mengumpulkan data penulis menggunakan studi kasus dengan metode observasi dan studi pustaka. Desain aplikasi web ini dibuat menggunakan bahasa pemrograman PHP, dibantu oleh xampp sebagai server web, MySQL untuk manajemen basis data, ERD (Entity Relationship Diagram) dan LRS (Logical Record Structure) untuk menggambarkan model data. Sedangkan metode pengembangan perangkat lunak penulis menggunakan Waterfall

Kata kunci: Web, Penyewaan, Lapangan Futsal
\end{abstract}

\begin{abstract}
Futsal sports have developed and are popular in Indonesia. Sumber Jaya Futsal is one of the providers of futsal field rental business in Tangerang. Sumber Jaya Futsal currently does not have a web-based system, the system for leasing futsal fields in Sumber Jaya Futsal is still conventional, where customers come directly or by calling to find out the schedule of available futsal fields. The rental transaction scheduling and report system is still using a notebook. Based on the problem, the purpose of this research is to produce a draft web application for futsal field rental at Sumber Jaya Futsal Tangerang. In this study to collect data the author uses case studies with methods of observation and literature. The design of this web application is made using the PHP programming language, assisted by xampp as a web server, MySQL for database management, ERD (Entity Relationship Diagram) and LRS (Logical Record Structure) to describe the data model. While the author's software development method uses the Waterfall Method.
\end{abstract}

Keywords: Web, Rental, Futsal Field

\section{PENDAHULUAN}

Futsal saat ini banyak diminati dan cukup berkembang sehingga banyak pelaku usaha membuka usaha penyewaan lapangan futsal. Sumber Jaya Futsal merupakan salah satu penyedia jasa penyewaan lapangan futsal yang ada di Tangerang. Sistem penyewaan yang ada di Sumber Jaya Futsal masih konvensional, yaitu pelanggan harus datang langsung ke tempat futsal untuk melihat jadwal lapangan futsal yang ingin disewa atau melalui telepon untuk menanyakan informasi jadwal lapangan yang masih kosong untuk disewa dan setelah itu pelanggan harus datang ke lokasi untuk melakukan transaksi. Akibat sistem yang masih manual menyebabkan keakuratan, ketepatan dan keefisienan sangat kurang (Syakur, 2014) Permasalahan yang dihadapi antara lain:

1. Dalam proses pemesanan masih konvensional, pelanggan datang langsung ke Sumber Jaya Futsal atau melalui telepon untuk melihat informasi jadwal lapangan dan melakukan transaksi pemesanan.

2. Kurangnya media promosi dan pemasaran masih konvensional, menggunakan spanduk.
3. Bukti pembayaran pelanggan masih dicatat dengan nota dan data sewa lapangan masih dicatat dalam buku besar .

Tujuan Penelitian ini dimaksudkan untuk:

1. Merancang sebuah aplikasi web penyewaan lapangan futsal untuk memudahkan dalam proses pemesanan

2. Memudahkan Sumber Jaya Futsal dalam memasarkan dan mempromosikan usaha penyewaan lapangan futsal menggunakan sebuah website.

3. Memudahkan Sumber Jaya Futsal dalam mengelola data transaksi penyewaan lapangan futsal.

Tinjauan Pustaka

1. Website

Website atau situs merupakan tempat penyimpanan data dan informasi dengan menggunakan topik tertentu. Diumpamakan situs web ini adalah sebuah buku yang berisikan sebuah topik tertentu, website atau situs web juga merupakan kumpulan dari halaman-halaman web yang saling berkaitan dalam web tersebut. (Kirana, 2013) 
2. PHP ( Hypertext Preprocessor)

PHP merupakan bahasa berbentuk script yang ditempatkan dalam server dan dieksekusi di dalam server untuk selanjutnya di transfer dan dibaca oleh client. (Adelheid \& Nst, 2012)

3. Pengembangan Perangkat Lunak

Metodologi pengembangan perangkat lunak yang penulis gunakan adalah model waterfall. "Model SDLC air terjun (waterfall) sering juga disebut sekuensial linier (sequential linier) atau alur hidup klasik (classis life cycle)". Model air terjun menyediakan pendekatan alur perangkat lunak secara sekuensial atau terurut dimulai dari analisa, desain, pengkodean, pengujian, dan tahap pendukung (support). (Sukamto \& Shalahuddin, 2014)

4. ERD

Entity Relationship Diagram ( ERD ) adalah suatu diagram untuk menggambarkan desain konseptual dari model konseptual suatu basis data relasional. ERD juga merupakan gambaran yang menghubungkan antara objek satu dengan objek lain dalam dunia nyata". (Utami \& Hartanto, 2012)

5. LRS

LRS (Logical Record Structured ) adalah sebuah model sistem yang digambarkan dengan sebuah diagram E-R akan mengikuti pola/aturan pemodelan tertentu dalam kaitannya dengan konversi ke LRS. (Hasugian \& Shidiq, 2012)

6. Pengujian Web

Black-Box Testing (pengujian Kotak Hitam). Black-box yaitu menguji perangkat lunak dari segi spesifikasi fungsional tanpa menguji desain dan kode program. Pengujian dimaksudkan untuk mengetahui apakah fungsifungsi, masukan, dan keluaran dari perangkat lunak sesuai dengan spesifikasi yang dibutuhkan. (Shalahuddin \& Sukamto, 2011)

\section{METODOLOGI PENELITIAN}

A. Teknik Pengumpulan Data

1. Observasi

Melalukan pengamatan pada Sumber Jaya Futsal Tangerang dan pada beberapa situs yang bersangkutan.

2. Studi pustaka

Melakukan studi pustaka dengan mengambil beberapa referensi baik dari artikel jurnal dan buku.

B. Metode Pengembangan Sistem

Metode yang digunakan pada pengembangan perangkat lunak ini menggunakan metode waterfall. Pada metode ini terdapat beberapa tahapan yaitu :

1. Analisa Kebutuhan Perangkat Lunak

Dalam merancang aplikasi web penyewaan lapangan futsal ini , penulis menggunakan beberapa sistem pendukung diantaranya: Adobe
Dreamweaver CS6, Mozilla Firefox, dan XAMPP.

2. Desain

Penulis menggunakan MYSQL dalam merancang database dan tabel. Desain antarmuka disesuaikan dengan tampilan website yang menyesuaikan dengan layar pengunjung.

3. Pembuatan Kode Program

Penulis menggunakan bahasa pemograman PHP dan HTML dalam membuat script coding program.

4. Pengujian

Penulis menggunakan Black Box Testing untuk mengetahui apakah aplikasi web penyewaan lapangan futsal yang telah dibuat sudah sesuai apa belum, agar tidak terjadi kesalahan pada saat dijalankan.

5. Pendukung ( support ) atau Pemeliharaan ( maintenance)

Untuk menjalankan aplikasi web penyewaan lapangan futsal yang telah dibuat, diperlukan suatu hardware sebagai pendukung sistemnya, yaitu CPU, hardisk, monitor, mouse, keyboard. Sedangkan software pendukungnya yaitu sistem operasi Microsoft Windows, Database Server MySQL, Database tool PhpMyadmin dan Web server Xampp.

\section{HASIL DAN PEMBAHASAN}

A. Analisis Kebutuhan Perangkat Lunak Analisa Kebutuhan Sistem pada Aplikasi Web Penyewaan Lapangan Futsal Pada Sumber Jaya Futsal terdiri dari kebutuhan pengunjung, member dan admin. Kebutuhan sistem pada Aplikasi Web ini meliputi :

1. Kebutuhan Pengunjung

a. Pengunjung dapat melihat informasi tentang lapangan beserta harga normal dan weekend

b. Pengunjung dapat mengetahui jadwal lapangan yang sudah di booking

c. Pengunjung dapat melakukan pendaftaran dan menjadi member

d. Pengunjung dapat mengirimkan kritik dan saran untuk perbaikan baik sistem maupun manajemen tempat futsalnya

2. Kebutuhan Member

a. Member dapat login dan booking lapangan

b. Member dapat membayar sebagian dahulu sebagai dana pertama dari total biaya booking dan pelunasan pembayaran di tanggal booking

c. Member dapat melakukan konfirmasi pembayaran yang sudah dibayar

d. Member dapat melihat status dari jadwal lapangan yang sudah di booking 
3. Kebutuhan Admin

a. Admin dapat menambah, mengedit dan menghapus data lapangan

b. Admin dapat mengelola data booking

c. Admin dapat mengelola data member

d. Admin dapat melihat data jadwal lapangan yang sudah di booking

e. Admin dapat melihat pemesanan, detail pemesanan, dan statusnya

f. Admin mengelola konfirmasi pembayaran yang sudah dilakukan oleh Member

g. Admin dapat mencetak laporan

B. Desain

Berdasarkan hasil analisa tentang kebutuhan yang diperlukan, maka rancangan basis data dan tampilan antar muka dari rancangan aplikasi web penyewaan lapangan futsal pada Sumber Jaya Futsal yaitu sebagai berikut:

Rancangan Basis Data

1. Desain Database

a. ERD (Entity Relationship Diagram ) pada aplikasi web penyewaan lapangan futsal pada Sumber Jaya Futsal.

Database menggunakan MySQL. Pada ERD ini terdapat beberapa tabel yaitu : Tabel Lapangan, Booking, User, Member, Pembayaran dan Tabel Kritik Saran_Pesan.

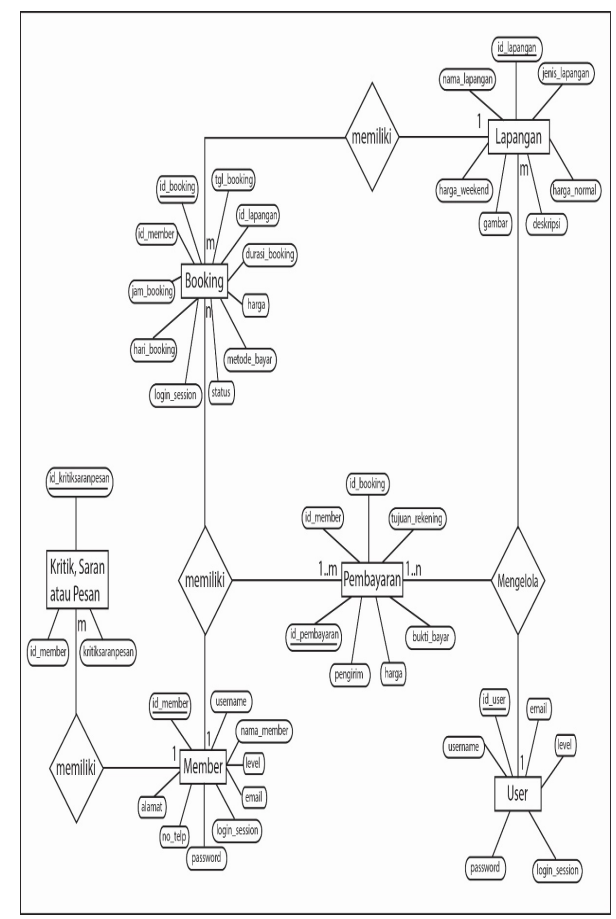

Sumber : Penelitian (2018)

Gambar 1:ERD Aplikasi Web Penyewaan

Lapangan Futsal b. LRS (Logical Record Structured) Pada aplikasi web penyewaan lapangan futsal pada Sumber Jaya Futsal

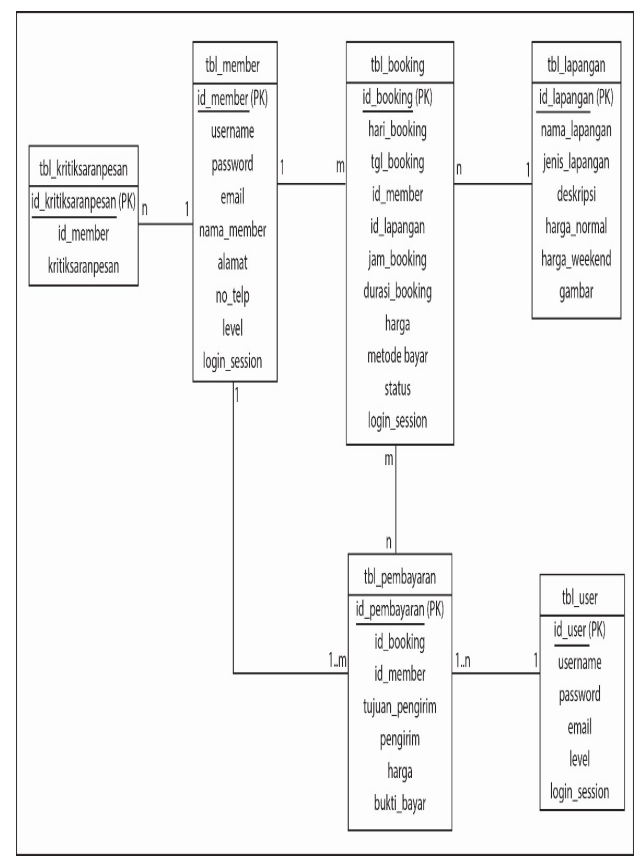

Sumber : Penelitian (2018)

Gambar 2: LRS Aplikasi Web Penyewaan Lapangan Futsal

2. Desain User Interface

a. Halaman Login Admin.

Administrator pada Sumber Jaya Futsal harus melakukan login terlebih dahulu untuk dapat menggunakan menu yang tersedia.

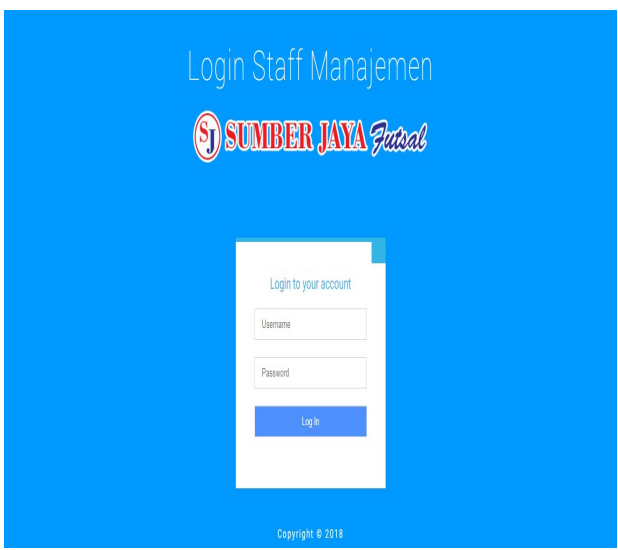

Sumber : Penelitian (2018)

Gambar 3. Halaman Login Admin 
b. Halaman Data Booking

Pada halaman ini admin dapat mengelola data booking

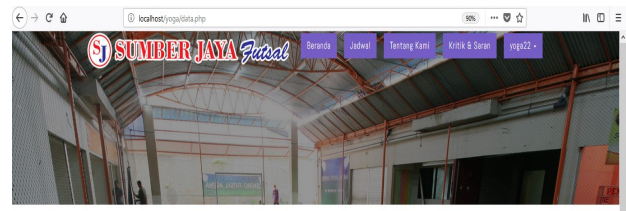

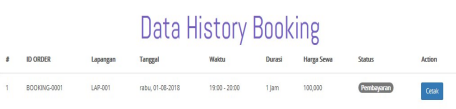

Sumber : Penelitian (2018)

Gambar 4. Halaman Data Booking

c. Halaman jadwal sewa lapangan

Pada halaman ini pengunjung dapat melihat informasi jadwal sewa lapangan

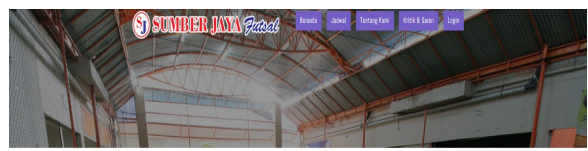

Jadwal Sewa Lapangan
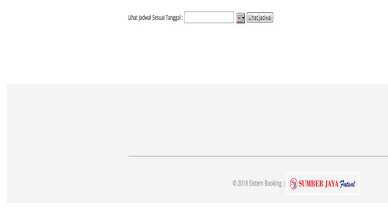

Sumber : Penelitian (2018)

Gambar 5. Halaman jadwal sewa lapangan

d. Halaman Booking Lapangan

Setelah login Member dapat langsung mengisi form booking lapangan.
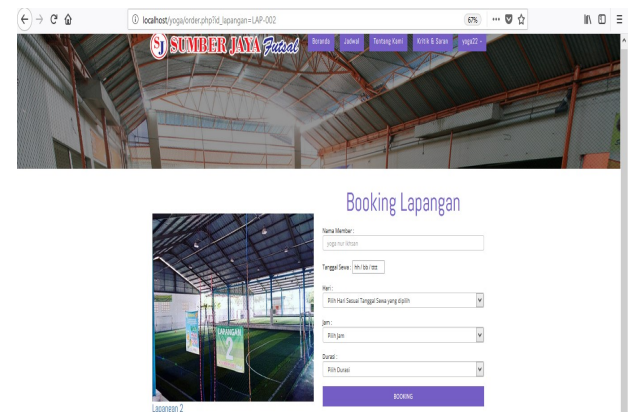

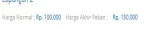

Sumber : Penelitian (2018)

Gambar 6. Halaman booking lapangan e. Halaman konfirmasi pembayaran Member dapat melalakukan konfirmasi pembayaran sewa lapangan
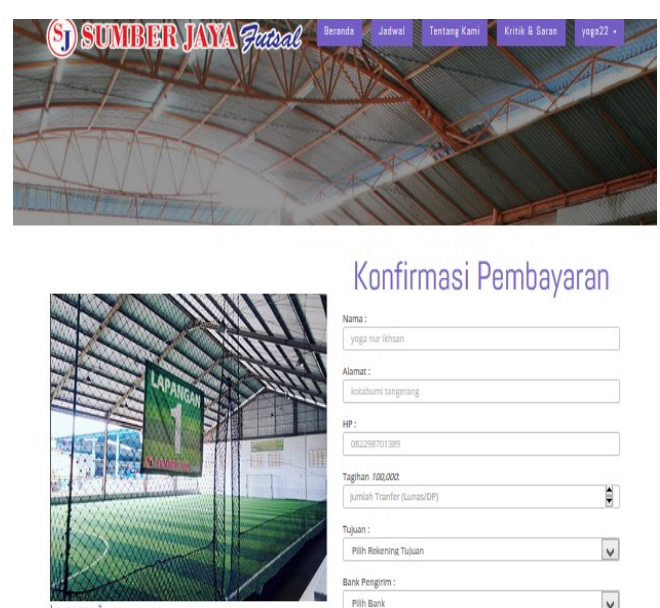

Konfirmasi Pembayaran

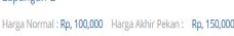

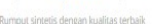

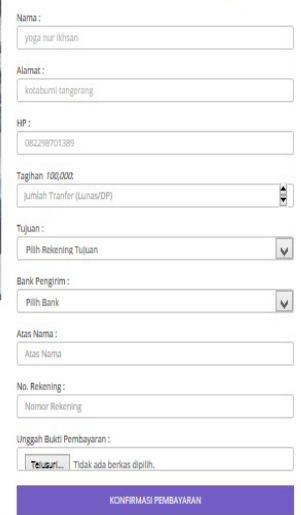

Sumber : Penelitian (2018)

Gambar 7. Halaman booking lapangan

f. Halaman cetak laporan

Admin dapat memcetak laporan keuangan Sumber Jaya Futsal

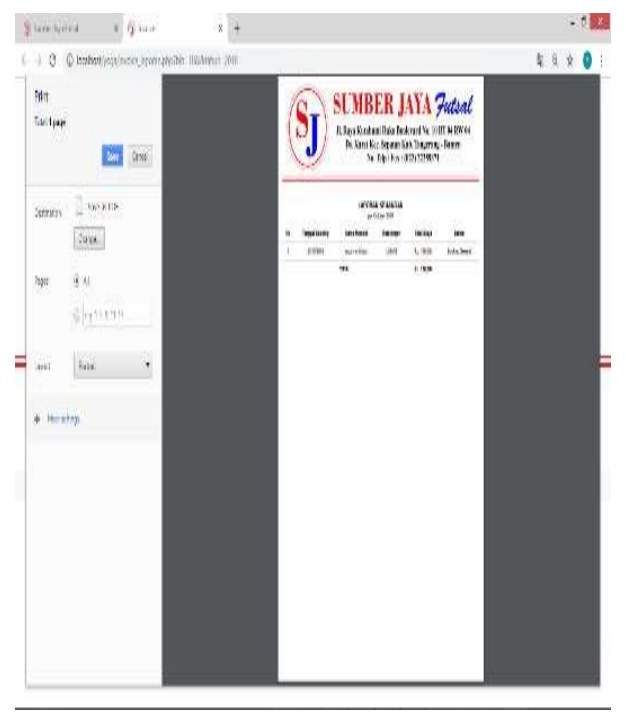

Sumber : Penelitian (2018)

Gambar 8. Halaman cetak laporan 


\section{Testing}

Pengujian terhadap program web yang dibuat menggunakan black box testing yang fokus terhadap proses masukan dan keluaran program. Dan hasil black box testing dapat dilihat pada Tabel 1 :

Tabel 1.Black Box Testing Halaman Registrasi Member

\begin{tabular}{|c|c|c|c|c|c|}
\hline$\overline{\mathrm{M}}$ & $\begin{array}{l}\text { Skersio } \\
\text { Pengrian }\end{array}$ & Tencous & $\begin{array}{c}\text { Hesilyge di } \\
\text { brrọlzan }\end{array}$ & $\begin{array}{c}\text { Hesil } \\
\text { Pengyijan }\end{array}$ & Kesimpilan \\
\hline $\bar{I}$ & 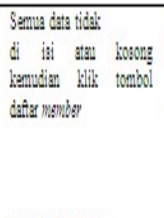 & 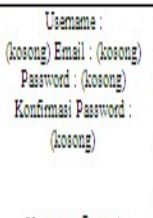 & 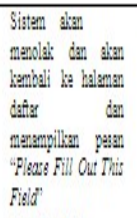 & $\begin{array}{l}\text { Served } \\
\text { margan }\end{array}$ & Valid \\
\hline 2 & 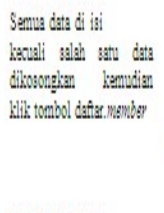 & 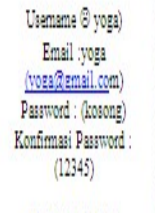 & 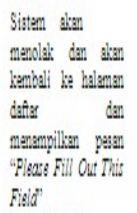 & $\begin{array}{l}\text { Serval } \\
\text { brespen }\end{array}$ & Valid \\
\hline 3 & 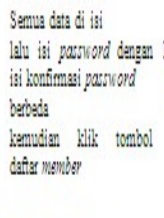 & 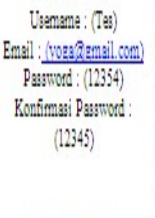 & 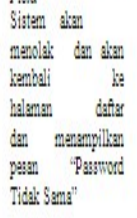 & $\begin{array}{l}\text { Serual } \\
\text { hragen }\end{array}$ & Valid \\
\hline 4 & $\begin{array}{l}\text { Semus data di isi } \\
\text { bemudien bili: tombol } \\
\text { datar member }\end{array}$ & 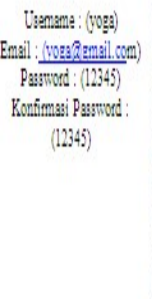 & 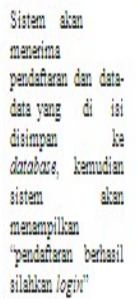 & $\begin{array}{l}\text { Served } \\
\text { marosn }\end{array}$ & Valid \\
\hline
\end{tabular}

\section{KESIMPULAN}

Penulis mencoba menarik kesimpulan dari pembahasan sebelumnya yaitu :

1. Dengan adanya rancangan aplikasi web penyewaan lapangan futsal ini diharapkan dapat memudahkan pelanggan dalam melakukan booking lapangan fulsal, melihat informasi jadwal lapangan dan melakukan konfirmasi pembayaran

2. Mempermudah Sumber Jaya Futsal untuk mempromosikan usaha penyewaan lapangan futsal melalui sebuah apliaksi web

3. Mempermudah Sumber Jaya Futsal dalam pengelolaan data transaksi penyewaan dan meminimalisir kesalahan.

\section{REFERENSI}

Adelheid, A., \& Nst, K. (2012). Buku Pintar Menguasai PHP dan MySQL. Media Kita.

Hasugian, H., \& Shidiq, A. N. (2012). Rancang Bangun Sistem Informasi Industri Kreatif Bidang Penyewaan Sarana Olahraga. Seminar Nasional Teknologi Informasi Dan Komunikasi Terapan (Semantik) 2012, 2012(Semantik 2012), 606-612. http://eprints.dinus.ac.id/202/

Kirana, D. C. (2013). Membuat WEBSITE Gratis Tanpa Guru. Dan Idea.

Shalahuddin, M., \& Sukamto, R. A. (2011). Java di Web. Informatika.

Sukamto, R. A., \& Shalahuddin, M. (2014). Rekayasa Perangkat Lunak: Terstruktur dan berorientasi objek. Informatika.

Syakur, M. L. (2014). Sistem Informasi Penyewaan Lapangan Futsal Pada Grindulu Futsal Pacitan. 3(4), 29-36.

Utami, E., \& Hartanto, A. D. (2012). System Basis Data Menggunakan Microsoft SQL Server. Andi. 